\title{
Hilary Mantel: Embodying Thomas Cromwell and Redefining Historical Fiction through 'Women's Writing'
}

\author{
Alaa Alghamdi \\ Department of Languages and Translation \\ Taibah University, Medina, Saudi Arabia
}

\begin{abstract}
Hilary Mantel's Tudor novels, Wolf Hall and Bring Up the Bodies, have been credited with rehabilitating the historical fiction genre with their vivid portrayal of life in King Henry's court, through the eyes of Thomas Cromwell. Mantel has received praise for her depiction of Cromwell, but also endured criticism for portraying him in an overly positive light. This paper examines the role of Mantel's work and depiction of Cromwell in the evolution and potential re-framing of the historical fiction genre. It seeks to achieve four things: to assess the compelling nature of her fiction, to situate her depiction of Cromwell in opposition to other depictions, to highlight her literary approach, and to contextualise Mantel's writing within 'women's writing'. Through this multifaceted approach it is conclusively established that although Mantel's narratives are situated within a female-dominated genre, they are told from a masculine perspective and gaze. Nonetheless, they still hold a significant subtext suggestive of the 'feminine'. This paper thereby reinforces the argument of feminist critic Julia Kristeva and shows Hilary Mantel and her 'embodied' depiction of Cromwell in a light previously unseen, holding merit for the genre of historical fiction as a whole.
\end{abstract}

Keywords: Cromwell, historical fiction, Mantel, semiotics, women's writing

Cite as: Alghamdi, A. (2018). Hilary Mantel: Embodying Thomas Cromwell and Redefining Historical Fiction through 'Women's Writing'. Arab World English Journal for Translation \& Literary Studies, 2 (1). DOI: http://dx.doi.org/10.24093/awejtls/vol2no1.9 